\title{
A CASE OF METAL EMBEDDED IN THE LENS: NORMAL VISION REGAINED AFTER NINE MONTHS.
}

\author{
BY \\ Leslie Buchanan, M.D., \\ SURGEON, GLASGOW EYE INFIRMARY.
}

THE following case appears to be of sufficient interest to merit publication.

J. K., aged 20 years, a brass finisher, came to the Glasgow Eye Infirmary on the 25th March, 1916, stating that he had been struck on the left eye, three days before, by a chip of metal, and that the sight of the eye was becoming dim.

There was a small wound of the cornea just beyond the pupillary margin of the iris in the meridian of nine o'clock. The anterior chamber was formed, and it was seen that the sphincter of the iris was cut just behind the wound. In the notch so formed there was a small mass of greyish tissue lying on the lens capsule. The lens was slightly opaque, and in the middle of it there was embedded what looked like a small chip of metal. The metal seemed to be lying a very little behind the centre of the lens and to measure about $1 \mathrm{~mm}$. in each direction. The eye was perfectly quiet, and there was no pain or tenderness. The tension was normal. R.V. 6/6, L.V. 6/60.

Ophthalmoscopic examination showed that the lens was slightly opaque, due to the presence in it of small faint clouds without any formation of radial lines of opacity. There was a slightly greater amount of clouding round the metal than elsewhere, but, using a +12 D. lens, it was clearly seen that the foreign body was certainly metal. (The patient stated that the metal was soft iron.)

As there was no indication for immediate operation, it was decided to leave matters as they were, and to watch the case carefully. The patient was instructed to attend (out-patient) each week.

Notes were made as follows:-

April 1st, 1916.- Eye quiet, lens rather more opaque. L.V. 6/60.

April 8th, 1916.-Eye quiet, lens not any more opaque. L.V. 6/60.

April 15th, 1916.-Eye quiet, lens seems to be clearing a little. L.V. $6 / 36$.

April 22nd 1916.-Eye improving steadily. L.V. 6/24. May 13th, 1916.- - Lens now clearing manifestly. L.V. 6/18. June 17th, 1916.-Centre of lens clearer, faint haze near periphery of lens only. Metal now seen very clearly with a $+12 \mathrm{D}$. lens. L.V. 6/14. 
July 17 th, 1916.--Lens almost entirely clear now, eye very quiet and well. Allowed to return to work. L.V. 6/9.

October 14th, 1916.-Eye very well, no discomfort from working. L.V. 6/6, 3 letters.

December 16th, 1916.-Eye still quiet and well, no cloud seen in the lens now. Metal visible very clearly, sharply-defined and perfectly bright (no rusting). L.V. 6/6, full.

As the patient is a very intelligent man, he is permitted to cease attendance at the Infirmary unless anything untoward develops.

He states that he suffers no inconvenience from the presence in the eye of the piece of metal or from the existence of the notch in the iris (which is quite small). He cannot observe any definite obstruction to vision due to the presence of the foreign body, but he can, of course, see the metal objectively, as it may be said, when he looks in a mirror, for it is clearly visible to anyone who observes the eye at all attentively.

\section{Remarks.}

There are several specially interesting features in this case.

The metal must have been quite aseptic to allow of its passage through the cornea and iris without giving rise to any infection. It was probably very hot at the moment it entered the eye, which would account for asepsis.

The wound of the lens capsule seems to have been plugged by a small portion of iris which was carried in by the metal and left in the little opening. This would explain, why the lens did not become entirely opaque.

The cloudy opacities in the lens cleared away entirely, leaving the metal as distinct as if it were lying in water. Probably the youth of the patient conduced to this satisfactory result.

The metal has not rusted, so far as can be detected, in the very least, which may be due to the fact that it was soft iron, not steel. The absence of rusting should conduce to the preservation of vision, and it is probable that a much better result will be attained than if extraction had been attempted. It is quite possible that opacity may develop when the influence of age begins to tell on the lens, but, at all events, several years of useful vision may be hoped for before this takes place.

There are several records in literature which point to the advisability of leaving nature to deal with such a case, amongst which may be quoted the following :-

Doyne (Transactions of the Ophthalmological Society U.K., Vol. XIV, p. 219), a chip of copper in an eye which retained useful vision for nearly thirty years.

Paderstein (Deutsche med. Wochenschr., 1909, S. 1,041), a chip of metal seen in a clear lens; eye retained full vision. 
Ginestous (Ophtal. Provinc., T. IX, p. 149), a case in which a chip of metal lodged in the lens and ultimately permitted of full vision.

Laqueur (Arch. f. Augenheilk., Bd. LIII, S. 97), two cases in which chips of glass were embedded in the lens and permitted of useful vision for several years.

Nottage (Ophthalmic Record, 1899, p. 78), a case in which a chip of metal was seen in a lens thirty years after injury; corrected vision $6 / 18$.

It is true that Elschnig has recorded a case (Klin. Monatsbl. $f$. Augenheilk., 1913, June), in which a chip of metal was successfully extracted from a lens (near its posterior pole), and in which normal vision was ultimately attained. Such a result must surely be even more rare than in the cases in which the metal is not extracted.

Doyne (Transactions of the Ophthalmological Society U.K., Vol. X, p. 198) mentioned a case in which metal had passed through the lens and lodged in the retina, leaving only a faintly visible track. Similar cases have been recorded by other writers, and Praun ("Die Verletzungen des Auges," Darmstadt, 1899) notes several instances in which lenses injured by needle-prick and other somewhat similar causes, have become hazy and ultimately cleared practically completely.

In nearly all the cases referred to the subjects have been quite young at the time of injury, and it seems safe to conclude that the age of the patient is a determining factor in the favourable result. Certainly, a most important point is that the metal should be aseptic.

\section{ABSTRACTS.}

\section{I.-ANATOMY.}

Wallis, G. F. C. (Margate.)-Some observations upon the anatomical relations of the optic nerves and chiasma to the sphenoid bone. Practitioner, January, 1917, p. 41.

This study is from the point of view of the rhinologist in regard to disease of the post-nasal sinuses, especially the sphenoidal. Eleven subjects were examined, the method followed being to remove the calvarium and then dissect away the brain piecemeal. The results, which showed considerable variation, are presented in a table. In no case did the chiasma rest wholly upon the optic 